\title{
Original
}

\section{A Novel PHAPI-related 35-kD Protein Highly Expressed in the Developing Brain}

\author{
Tokutada SATo ${ }^{1)}$, Tamio Hagiwara ${ }^{2)}$, Kazuko AokI ${ }^{3)}$, Hiroshi KURAISHI ${ }^{1)}$, \\ Yutaka NishigaKI $^{1}{ }^{1}$, Kei TATENO ${ }^{1)}$, Takayoshi TANAKA ${ }^{1)}$, Fumiyo TAKeDA $^{2)}$ \\ and Minoru TAKEDA ${ }^{1)}$
}

\begin{abstract}
We have purified a $35-\mathrm{kD}$ protein which was expressed mainly in the fetal and early postnatal rat brain cytosol fraction. Partial amino acid sequence analysis of the purified $35-\mathrm{kD}$ protein showed identity with the sequence of putative human leukocyte antigen (HLA) class II associated protein I (PHAPI). To clone cDNAs encoding the $35-\mathrm{kD}$ protein, reverse transcription-polymerase chain reaction (RT-PCR) was performed using primers designed on the basis of the reported PHAPI cDNA nucleotide sequence. We obtained three partial cDNA clones whose nucleotide sequences showed high similarity to PHAPI. The deduced amino acid sequences of these cDNA clones also showed similarity to PHAPI. The region of acidic amino acids at the C-terminal end of the protein suggested that this molecule may function as a transcription factor. This $35-\mathrm{kD}$ PHAPI family protein may therefore function in the determination or differentiation of fetal and early postnatal brain.
\end{abstract}

Key words : MHC, HLA-DR, brain, development, acidic protein

\section{Introduction}

A number of proteins have been isolated that are specifically expressed in the developing CNS, including vitamin D-dependent $28-\mathrm{kD}$ calcium-binding protein (Calbindin-D) ${ }^{1)}$, elongation factor-1 $\alpha(\text { EF-1 })^{2)}$, cortex-enriched protein tyrosine phosphatases (CPTPs $)^{3)}$ and $\mathrm{D}$ type cyclins ${ }^{4)}$. We have previously identified a $30-\mathrm{kD}^{5)}, 40-\mathrm{kD}^{6)}$ and $33-\mathrm{kD}^{7)}$ protein that were only expressed in fetal and early postnatal rat brain cytosol fractions, suggesting that these proteins may play important roles in neuronal development. In this study, we have purified a $35-\mathrm{kD}$ protein expressed predominantly in the developing brain cytosol fraction, which showed amino acid and nucleotide sequence similarity to putative human leukocyte antigen (HLA) class II associated protein I (PHAPI).

\footnotetext{
1) Department of Biochemistry, Showa University School of Medicine, 1-5-8 Hatanodai, Shinagawa-ku, Tokyo 1428555, Japan.

2) Institute of Molecular Oncology, Showa University School of Medicine.

3) Department of Medical Biology, Showa University School of Medicine.
} 


\section{Materials and Methods}

\section{Material}

Pregnant and adult female Wistar rats of various ages were purchased from Saitama Experimental Animals Supply Co., Ltd (Saitama, Japan). Anion exchange column, TSK DEAE-5PW $(7.5 \mathrm{~mm}$ inner diameter $\times 75 \mathrm{~mm})$ and reverse phase column, Shodax C18-5B $(4.6 \mathrm{~mm}$ inner diameter $\times 250 \mathrm{~mm})$ were purchased from Tosoh Corporation (Tokyo) and Showa Denko K. K. (Tokyo), respectively. Other chemicals were obtained from commercial sources.

\section{Preparation and Purification of the 35-kD Protein}

Rat brains were removed under anesthesia with ether. The preparation of cytosol fraction from whole brains and the isolation of proteins were carried out as described previously ${ }^{5-7)}$. Briefly, the cytosol fraction was subjected to a high performance liquid chromatography (HPLC) using a TSK DEAE-5PW column. After fractionation by ion-exchange chromatography, proteins in each fraction were seperated by sodium dodecylsulfatepolyacrylamide gel electrophoresis (SDS-PAGE) using Laemmli's buffer system ${ }^{8)}$. The fractions were subjected to a preparative SDS-PAGE to separate large amounts of the protein.

\section{Partial Amino Acid Sequencing of the 35-kD Protein}

All procedures, except the acromobacter protease I (API)-digestion, were carried out at room temperature. Forty micrograms of the purified $35-\mathrm{kD}$ protein was digested in $0.5 \mathrm{ml}$ of $0.1 \mathrm{M}$ Tris- $\mathrm{HCl}$ ( $\mathrm{pH} 9.0$ ) containing $2 \mathrm{M}$ urea with $0.5 \mathrm{mg}$ of API for 24 hours at 37 ${ }^{\circ} \mathrm{C}$. The digested peptides were seperated by Shodex C18-5B column equilibrated with $0.05 \%$ trifluoroacetic acid. The elution was performed with a $90 \mathrm{ml}$ linear gradient of acetonitrile from $0 \%$ to $60 \%$ in $0.05 \%$ trifluoroacetic acid at a flow rate of $1 \mathrm{ml} / \mathrm{min}$. Peptides were detected by measuring absorbance at $215 \mathrm{~nm}$. The amino acid sequences of the separated peptides were analysed with a Milligen/Biosearch ProSequencer model 6625 (PerSeptive Biosystems, Framingham, MA). The homology search was performed with the data bank of Software Development Co (NBRF protein database).

\section{Reverse Transcriptase PCR}

Poly $\mathrm{A}^{+}$RNA was purified from nine brains of E17 rat fetuses using a commercial mRNA purification kit (Pharmacia Biotech LKB Biotechnology, Piscataway, NJ) based on an oligo-dT method. Approximately $240 \mathrm{ng}$ of purified mRNA was incubated in $20 \mu 1$ of mixture containing $100 \mathrm{pmol}$ random hexamer (Takara, Kyoto), RT-buffer (final concentration : $50 \mathrm{mM}$ Tris- $\mathrm{HCl}, \mathrm{pH} 8.3,75 \mathrm{mM} \mathrm{KCl}, 3 \mathrm{mM} \mathrm{MgCl}_{2}$ ), $28 \mathrm{U} \mathrm{RNasin}$ (Promega, Madison, WI), $0.01 \mathrm{M}$ dithiothreitol (Gibco BRL Products, Gaithersburg, MD), $1 \mathrm{mM}$ dNTP (Wako Pure Chemical Industries, Ltd., Osaka), and $200 \mathrm{U}$ Superscript II reverse transcriptase (Gibco BRL Products) for $1 \mathrm{~h}$ at $42{ }^{\circ} \mathrm{C}$. For PCR, primers were synthesized on the basis of the published human PHAPI cDNA sequences ${ }^{9)}$. Two sense primers (primer A : 5'-ATGGAGATGGGCAGACGGA) and primer B : 5'-CAATTGCGAGGTAACCAACC) and two antisense primers (primer C: 5'-CATTTTCTCGGTAGTCGTTCA and primer D: 5'-AGTCATCATCTTCTCCCTCAT) corresponding to the 


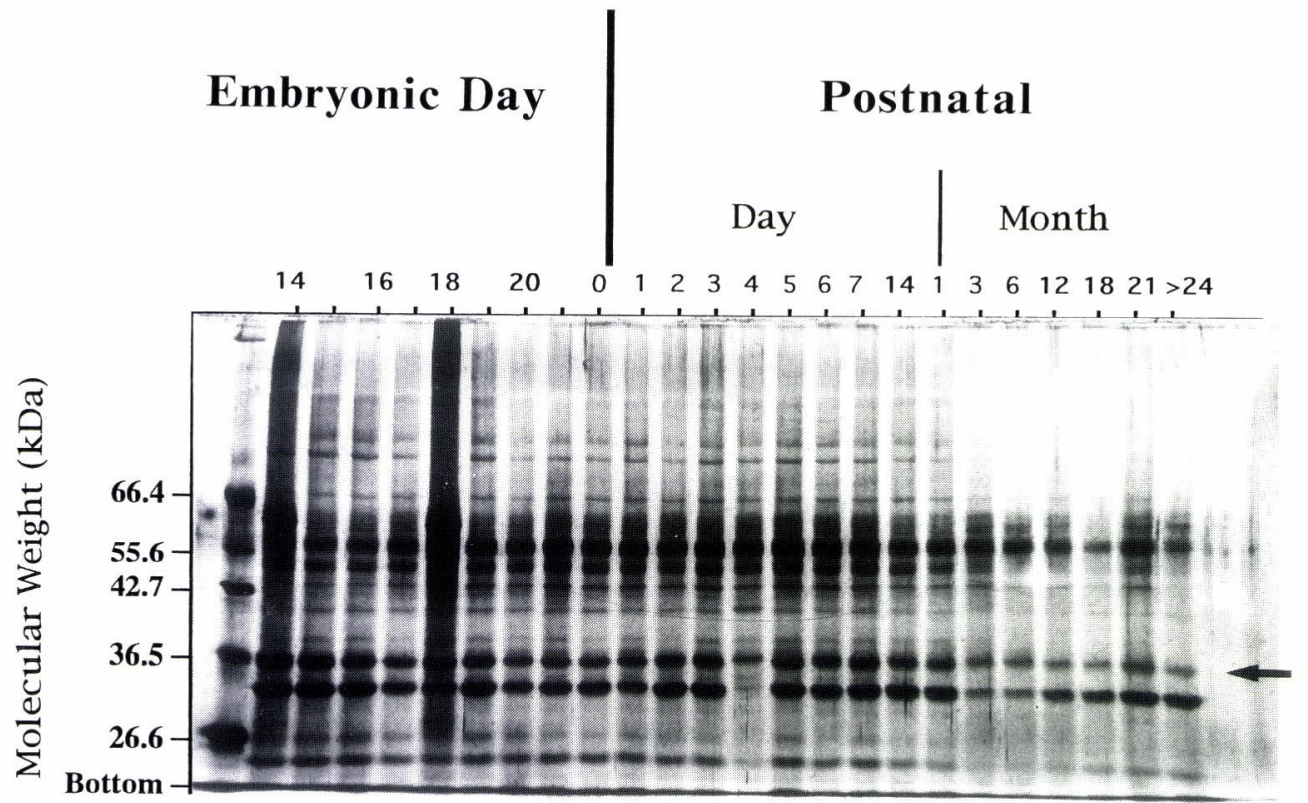

Fig. 1. Temporal expression of the $35-\mathrm{kD}$ protein in developing rat brain. The $35-\mathrm{kD}$ protein is indicated by an arrow.

nucleotide sequence from 104-122, 466-485, 486-506 and 831-850, respectively, were prepared. PCR was performed in a volume of $100 \mu 1$ containing Taq DNA polymerase buffer (final concentration: $10 \mathrm{mM}$ Tris/ $\mathbf{H C l}, \mathrm{pH} 8.3,50 \mathrm{mM} \mathrm{KCl}, 1.5 \mathrm{mM} \mathrm{MgCl}_{2}$ ), 200 $\mu \mathbf{M}$ of each dNTP (Takara), 100 pmol of each primer, $2.2 \mathrm{U}$ Taq DNA polymerase (Takara) and $0.484 \mu \mathrm{g}$ Taq Start Antibody (CLONTECH Laboratories Inc., Palo Alto, CA). The reactions were performed on the Program Temp Control System PC-700 (ASTEC, Carlsbad, CA) using a program with initial denaturation at $94{ }^{\circ} \mathrm{C}$ for 3 min followed by 40 cycles of denaturation for $1 \mathrm{~min}$ at $94^{\circ} \mathrm{C}$, annealing for $1 \mathrm{~min}$ at $42^{\circ} \mathrm{C}$ and extension for $2 \mathrm{~min}$ at $72^{\circ} \mathrm{C}$. After the last cycle, final extension was performed for $10 \mathrm{~min}$ at $72^{\circ} \mathrm{C}$. Ten $\mu 1$ of each $\mathrm{RT}$-PCR product was resolved by electrophoresis on a $2.5 \%$ Amplisize Agarose (Bio-Rad, Hercules, CA) gel containing $0.04 \mathrm{M}$ Tris-acetate, $0.001 \mathrm{M}$ EDTA and $0.05 \mu \mathrm{g} / \mathrm{ml}$ ethidium bromide. The cDNA was extracted with Tris-EDTA buffer ( $\mathrm{pH}$ 8.0) from the gel using the Sephaglas Band Prep. Kit (Nycomed Amersham, Little Chalfont, UK), according to the instruction manual. The purified cDNA was ligated into the Sma I site of pBluescript II $(\mathrm{SK}+)$. The final construct was used to transform Escherichia coli XL-1 blue, and the plasmid was isolated by the alkaline-SDS preparation and purified by $20 \%$ polyethylenglycol $/ 2.5 \mathrm{M} \mathrm{NaCl}^{10)}$. The cDNA was sequenced with a DNA Sequencing System Model 373A (Applied Biosystems, Foster City, CA).

\section{Results}

Isolation of the $35-k D$ protein from the cytosol of fetal brain

We have previously compared brain cytosol protein maps at different stages to detect proteins transiently expressed in restricted periods. More than 30 proteins were specifically 


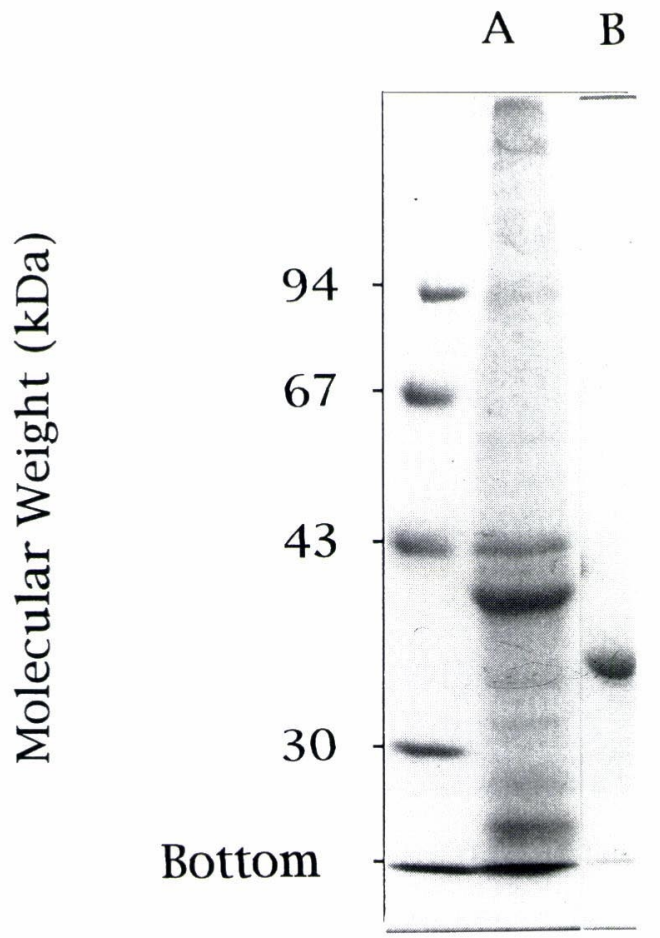

Fig. 2. Confirmation of the isolation of the $35-\mathrm{kD}$ protein by SDS-PAGE. A : pooled fraction (45-50) from ion-exchange chromatography by TSK DEAE-5PW in E14. B : the isolated $35-\mathrm{kD}$ protein. Molecular weight markers are indicated on the left side.

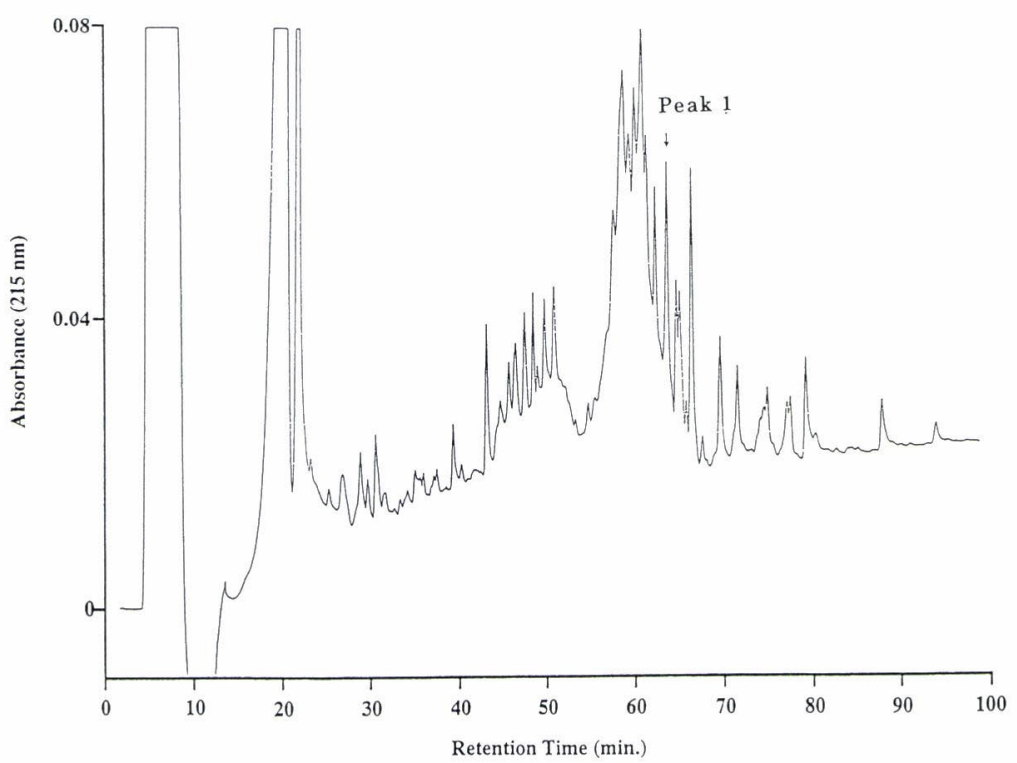

Fig. 3. Peptide map analysis of the $35-\mathrm{kD}$ protein by RP-HPLC on a Shodex C18-5B column after digestion by the lysylendopeptidase (AP1). The peak marked by Peak 1 could be sequenced. 
The $35 \mathrm{kDa}$ Protein Fragment

Putative HLA-DR Associated Protein I - K L K K LE L SD NR V S G G L E V L A E KC P N 65

Fig. 4. Comparison of amino acid sequence between the portion that could be sequenced in the 35-kD protein and the corresponding portion in PHAPI.

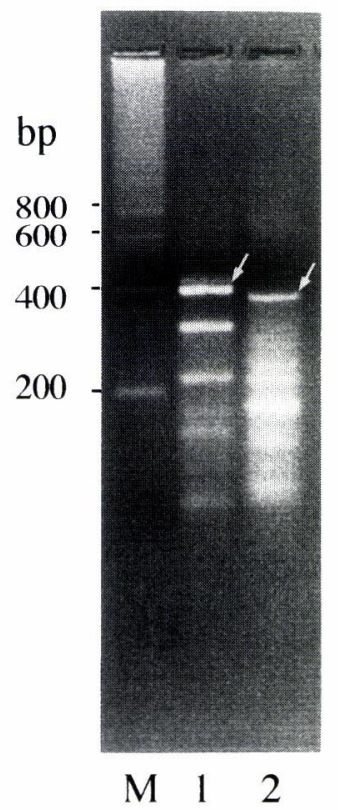

Fig. 5. Agarose gel electeophoresis of RT-PCR products. $\mathrm{M}$ : markers, 1 : products of the 5'-terminal portion using primers $\mathrm{A}$ and $\mathrm{C}, 2$ : products of the 3 '-terminl portion using primers $\mathbf{B}$ and $\mathrm{D}$. The bands of the length corresponding to the each portion of PHAPI are indicated by arrows.

detected in the sample from E14 fetal brain ${ }^{5)}$. The protein described in this report, one of these proteins, was detected in HPLC fraction 49 and its molecular weight was estimated to be $35-\mathrm{kD}$ on SDS-PAGE. The $35-\mathrm{kD}$ protein was detected in the embryonic day 14-21 (E14-E21) prenatal stage and expression was reduced by postnatal 14 day (Fig. 1). The 35-kD protein was isolated from the pooled fraction by SDS-PAGE (Fig. 2).

\section{Determination of partial amino acid sequence of the 35-kD protein}

The purified $35-\mathrm{kD}$ protein was digested with lysylendpeptidase API, and peptide fragments were seperated on a Shodax C18-5B reverse phase column. The peptide map is shown in Fig. 3. The amino acid sequence of peak 1 (shown in Fig. 3) was determined by automated amino acid sequencer. The partial sequence was analyzed by computer homology search for comparison with known proteins. The peptide fragment derived from the purified $35-\mathrm{kD}$ protein was found to have identity with residues 65-89 of PHAPI (Fig. 4). 
(I)

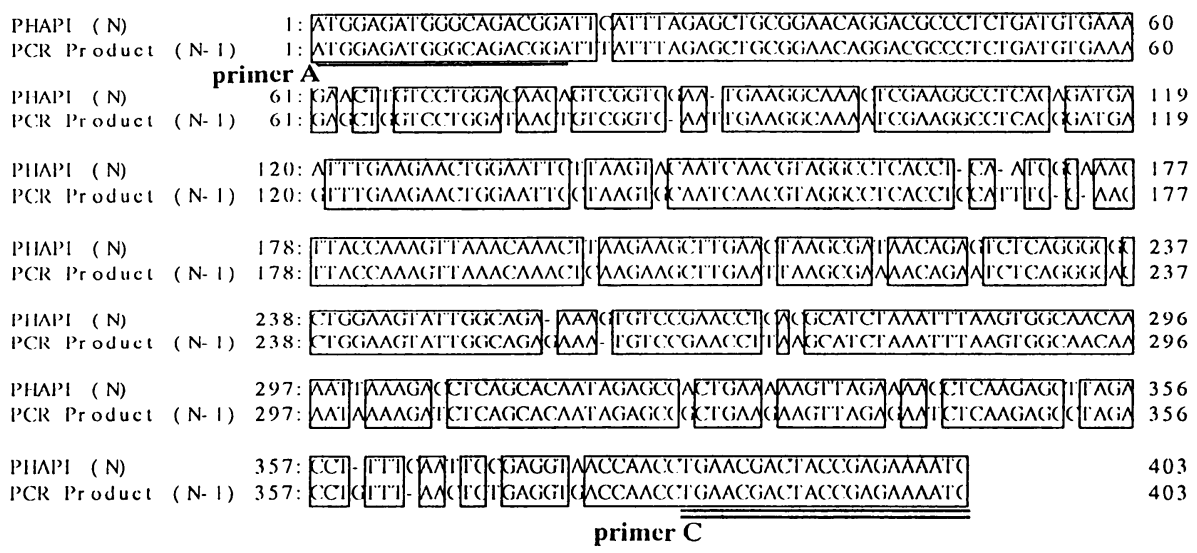

\section{( II )}

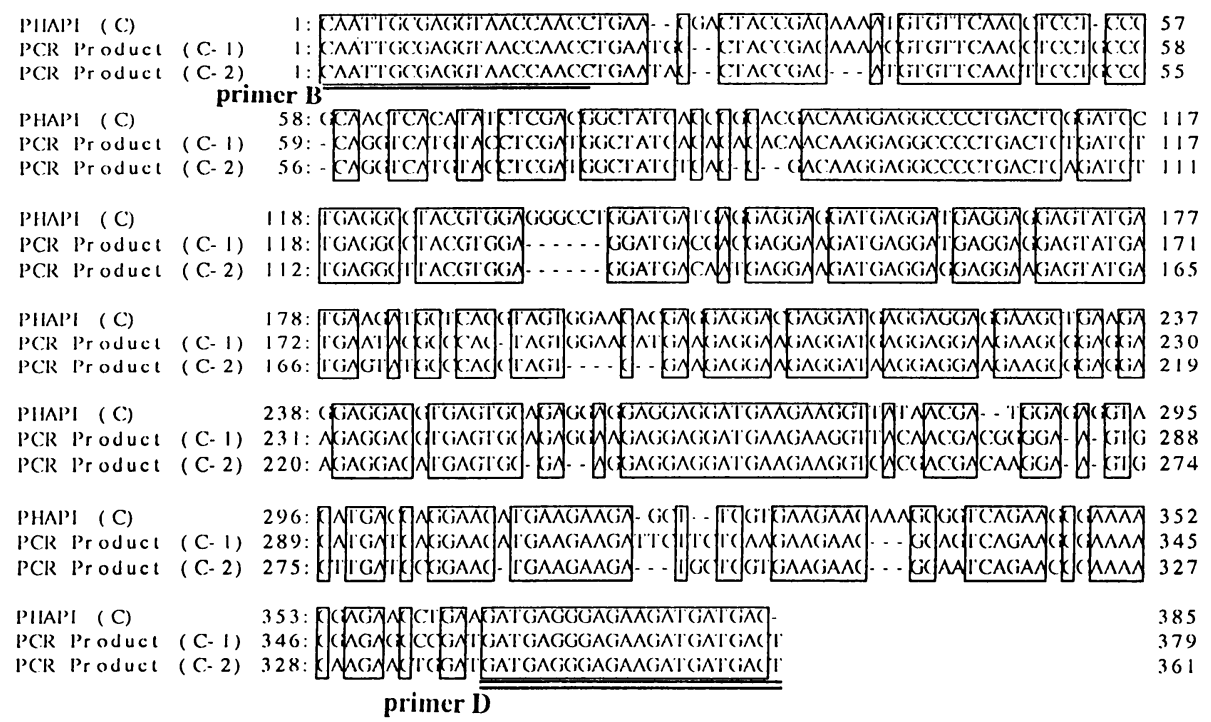

Fig. 6. (I) Comparison of the 5'-terminal nucleotide sequence between PHAPI and the 35-kD protein A : annealing site of sense primer $\mathrm{C}$ : annealing site of antisense primer.

(II) Comparison of the 3'-terminal nucleotide sequence between PHAPI and the 35-kD protein B : annealing site of sense primer D : annealing site of antisense primer.

Cloning of $c D N A s$ encoding the brain $35-k D$ protein.

To confirm that the $35-\mathrm{kD}$ protein was a rat homologue of human PHAPI, we cloned cDNAs encoding this protein. Two sets of oligonucleotide primers derived from human PHAPI cDNA sequences were used in RT-PCR of E17 rat fetal brain poly $\mathrm{A}^{+}$RNA. One primer set amplified the 5'-terminal half of the PHAPI cDNA and the other set amplified 
PHAPI : MEMGRRIHLE LRNRTPSDVK ELVLDNSRSN EGKLEGLTDE FEELEFLSTI NVGLTSIANL

N-1 : MEMGRRLHLE LRNRTPSDVK ELVLDNSRSN EGKLEGLTDE FEELEFLSTI NVGLTSIANL

PKLNKLKKLE LSDNRYISGGLL EVLAEKCPNL THLNLSGNKI KDLSTIEPLK KLENLKSLDC

EKLNKLKKLE LSENR ISGDL EVLAEKCPNL_KHLNLSGNKL KDLSTUEPLK KLENLKSLDL]

FNCEVTNLND YREN

FNCEVTNLND YREN

PHAPI : NCEVTNLNDYY RENVFKLLPQ LTYYLDGYDRD DKEAPDSLAE GYVESLDDEE EDEDEEEDED

C-1 : NCEVTNLNAY RENVFKLLPQ VMYLDGYDRD NKEAPDSDVE GYVE **DDD******EEDED

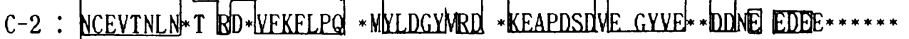

EEEYDEDAQV VEDEEDEDEE EEGEEEDVSG EEEEDEEGYN DGEVDDEEDE EELGEEERG EEEYDEYAQV VEDEEEEDEE EEGEEEDVSG EEEEDEEGYN DGEVDDEEDE EDSSEEEGSO

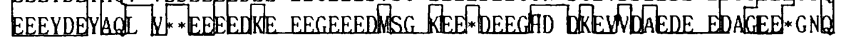

KRKREPEDEG EDDD

KRKREPDDEG EDDD

NPKSOELDDEG EDDD

Fig. 7. Deduced amino acid sequence of the $35-\mathrm{kD}$ protein. N-1 was deduced from PCR product (N-1). C-1 and C-2 were deduced from PCR product (C-1) and (C-2). Asterisks show deletions of amino acid residues.

the 3'-terminal half. The PCR products from primers A/C and B/D were $400 \mathrm{bp}$ and 380 bp in size, respectively, which were consistent with the molecular sizes predicted from human PHAPI (Fig. 5). These products were subcloned and several cDNA clones were isolated and sequenced. The sequence of the 5'-terminal clone showed $91 \%$ similarity to PHAPI. Two kinds of sequences were detected in the 3'-terminal site, which showed $84 \%$ (C-1) and 76\% (C-2) similarity with PHAPI, respectively (Fig. 6). The amino acid sequences deduced from the clone sequences showed $98 \%$ identity with the PHAPI protein at the N-terminal site. Furthermore, at the C-terminal end they showed $83 \%(\mathrm{C}-1)$ and 64\% (C-2) identity with PHAPI (Fig. 7). Other PCR products were also sequenced, but showed no similarity to PHAPI in both the cDNA and the deduced amino acid sequence.

\section{Discussion}

We have recently purified, obtained cDNA clones and determined the primary structures of a number of proteins which were expressed in an age-dependent manner in rat brain cytosol fraction ${ }^{6,7)}$. In this report, we describe a 35-kD protein which was expressed predominantly in the fetal and early postnatal brain. The partial amino acid sequences of the purified $35-\mathrm{kD}$ protein showed similarity to PHAPI. cDNA clones for this $35-\mathrm{kD}$ protein were obtained by RT-PCR of fetal rat brain RNA using primers designed on the basis of the reported uncleotide sequence of human PHAPI cDNA. The nucleotide sequences of the cDNA clones encoding the 35-KD protein showed similarity with human PHAPI cDNA sequences. Vaesen et al. ${ }^{9)}$ first isolated the PHAPI protein from cytosolic fraction of human lymphoblastoid H2LCL B-cell line. Based on the primary structure of PHAPI, they speculated that it was involved in the generation of intracellular signalling events that leaded to regulation of transcriptional activity after binding of a ligand to HLA class II molecules. However, the molecular mechanism of action of PHAPI still remains to 
be clarified. The high level of sequence similarity observed between our novel 35-kD protein and human PHAPI suggests that this rat brain cytosolic protein might be a PHAPI family protein.

MHC class II molecules are expressed on the surface of antigen-presenting cells (APCs) such as lymphocytes, macrophages, dendritic cells and activated T-cells ${ }^{11)}$. However, the function of antigen-presenting cells in the brain remains controversial. Although several brain cells, including microglia, astrocytes and endothelial cells, act as APCs in vitro, it is generally assumed that there is low level or no expression of MHC class II antigen in the brain ${ }^{12)}$. However, recent new immunocytochemical techniques have suggested that rat or mouse resting microglia specifically and constitutively express MHC class II antigens in certain locations such as the white matter in, for example, the corpus callosum or wihin the cerebellum $^{13)}$. In the human nervous system, different levels of MHC class II antigen expression have been described. The resting microglia constitutively express MHC class II antigens mainly in the white matter ${ }^{14)}$ in addition to the MHC class II -immunoreactive perivascular cells described by Graeber et al. ${ }^{15)}$.

We purified the $35-\mathrm{kD}$ protein from whole brain, and cannot therefore identify the specific region of expression. Glial cells such as astroglia and microglia, proliferate and differentiate in late prenatal and early postnatal human brain ${ }^{16,17)}$. Furthemore, axons and synapses have been shown to be overproduced in the white matter, and subsequently eliminated by active microglia to recoganize the $\mathrm{CNS}^{18,19)}$. Since the $35-\mathrm{KD}$ protein is also highly expressed in that period, it might be derived from glial cells. Although the biological function of the $35-\mathrm{kD}$ protein in the brain is unknown, a long stretch of acidic amino acids at the $\mathrm{C}$-terminal end suggests that this protein may be a transcription factor.

The expression of MHC class II antigens ( Ia) in the nervous system has become a recent focus of investigation because of their presumed active roles in immune-mediated diseases such as multiple sclerosis ${ }^{20,21)}$. More recently, the emergence of Ia-expressing cells has also been reported in non-immunological neurodegenerative diseases such as Alzheimer's disease and Parkinson's disease ${ }^{22}$.

\section{References}

1) Kurobe N, Inaguma $Y$, Shinohara $\mathbf{H}$, Semba $R$, Inagaki $T$ and Kato $\mathbf{K}$ : Developmental and age-dependent changes of $28-\mathrm{kD}$ calbindin-D in the central nervous tissue determined with a sensitive immunoassay method. J Neurochem, 58 : 128-134 (1992)

2) Lee S, Wolfraim LA and Wang E : Differential expression of S1 and longation factor-1 during rat development. J Biol Chem, 268 : 24453-24459 (1993)

3) Sahin $\mathbf{M}$ and Hockfield $\mathbf{S}$ : Protein tyrosine phosphatases expressed in the developing rat brain. $J$ Neurosci, 13 : 4968-4978 (1993)

4) Tamura T, Okada $M$ and Nakagawa $H$ : Differential expression of $D$ type cyclins during neuronal maturation. Neurosci Lett, 168 : 229-232 (1994)

5) Aoki K, Hagiwara T, Kuraishi H, Sato T, Nishigaki Y, Tateno K, Tanaka T, Takeda F, Matuda I, Takeda $\mathbf{M}$ and Okamoto $\mathrm{K}$ : Characterization of a novel $30-\mathrm{kD}$ protein expressed in prenatal and early postnatal rat brain cytosol. Showa Univ J Med Sci, 9 : 57-65 (1997)

6) Nishigaki Y, Hagiwara T, Aoki K, Kuraishi H, Sato T, Tateno K, Tanaka T, Takeda F and Takeda M: Investigation of putative human leukocyte antigen-DR associated protein II (PHAPII) homologue expressed in the fetal rat brain. Showa Univ J Med Sci, $10: 119-128$ (1998)

7) Kuraishi H, Hagiwara T, Sato T, Nishigaki Y, Aoki K, Takeda F and Takeda M: Purification and partial amino acid sequence of fetal brain specific 33-kD protein. Showa Univ J Med Sci, 10 : 149-156 (1998)

8) Laemmli UK : Cleavage of structural proteins during the assembly of the head of bacteriophage T4. Nature, $227: 680-685(1970)$ 
9) Vaesen M, Watanabe SB, Gotz H, Awni LA, Cole T, Zimmermann B, Kratzin HD and Hiischmann N : Purification and characterization of two putative HLA class II associated proteins : PHAPI and PHAPII. Biol Chem Hoppe-Seyler, 375 : 113-126 (1994)

10) Sambrook J, Fritsch EF and Maniatis T: Molecular Cloning-A Laboratory Manual. 2nd ed. Three vols. Cold Spring Harbour Laboratory Press, Cold Spring Harbour, NY (1989)

11) Kaufman JF, Auffray C, Korman AJ, Shackelford DA and Strominger J : The class II molecules of the human murine major histocompatibility complex. Cell, $36: 1-13$ (1984)

12) Wekerle $\mathbf{H}$ : Myelin specific, autoaggressive $\mathbf{T}$ cell clones in the normal immune repertoire: their nature and their regulation. Int Rev Immunol, $9: 231-241$ (1992)

13) Gehrmann $J$ and Kreutzberg GW : Characterization of two new monoclonal antibodies directed against rat microglia. J Comp Neurol, 313 : 409-430 (1991)

14) Cuzner ML, Hayes GM, Newcombe $J$ and Woodroofe $M N$ : The nature of inflammatory components during demyelination in multiple sclerosis. J Neuroimmunol, $20: 203-209$ (1988)

15) Graeber MB, Streit WJ, Büringer D, Sparks DL and Kreutzberg GW : Ultrastructural location of major histocompatibility complex (MHC) class II positive perivascular cells in histologically normal brain tissue. $J$ Neuropathol Exp Neurol, 51 : 303-311 (1992)

16) Fujita S, Tsuchihashi $Y$ and Kitamura $T$ : Origin, morphology, and function of the microglia. In: Glial and Neuronal Cell Biology. Vidrio EA (Ed), Alan R Liss Inc., New York, pp. 141-210 (1981)

17) Dobbing J : Undernutrition and the developing brain. Am J Dis Child, 120 : 411-415 (1970)

18) Innocenti GM, Koppel $\mathrm{H}$ and Clarke $\mathrm{S}$ : Transitory macrophages in the white matter of the developing visual cortex. I. Light and electron microscopic characteristics and distribution. Dev Brain Res, 11 : $39-53$ (1983)

19) Huttenlocher PR and de Courten $C$ : The development of synapses in striate cortex of man. Hum Neurobiol, 6 : 1-9 (1987)

20) Cuzer ML, Hayes GM, Newcombe $J$ and Woodroofe $M N$ : The nature of inflammatory components during demyelination in multiple sclerosis. J Immunol, 20 : 203-209 (1988)

21) Hauser SL, Bhan AK, Gilles F, Kemp M, Karr C and Weiner HL: Immunohistochemical analysis of the cellular infiltrate in multiple sclerosis lesions. Ann Neurol, $19: 578-587$ (1986)

22) McGeer PL, Itagaki S, Boyer BE and McGeer EG: Reactive microglia are positive for HLA-DR in the substantia nigra of Parkinson's and Alzheimer's disease brains. Neurology, 38 : 1285-1291 (1988)

[Received February 27, 1998 : Accepted March 5, 1998] 